\title{
Strategic International Environment - Is Europe Ready for a New Concert of the Superpowers? Central European Perspectives
}

\begin{abstract}
There is no doubt that the strategic international environment is subject to extremely dynamic changes today. Relative stabilization in Europe built and won as a result of democratic changes following the Cold War era, is being replacedin many areas by destabilization. New challenges are gaining importance and threats. Worth mentioning are: unpredictable political changes, terrorism, cyberthreats, assymetric challenges causing tensions, climate changes, and in the social sphere: especially migrations and demographics. Uncertainty is growing, risks are increasing both in global dimension and regional, which affects the situation of Poland and neighboring countries. The uncertainty and unpredictability is now the key factor in development of relationships between different actors in the international environment.
\end{abstract}

Key words: Uncertainty, Unpredictability, Europe, European Union, Security, Changes, V4, Weimar Triangle, Migrations, Demographics, Ecology

Mutual influences of states and interest groups change vectors. The stable balance of forces of the Old Continent - Europe and the United States in the understanding of transatlantic ties, cooperation and attachment to common values and objectives loses importance for a new distribution on the political map of the world. Greater importance is given to: China's economic powerhouse, strong development of India, instability of the Middle East, crises and disasters on the African continent, as well as Russia's influence.

^ Łukasz Polinceusz - Casimir Pulaski Foundation, e-mail: lpolinceusz@pulaski.pl, ORCID: 0000-0002-4528-8752. 
The stability of the European Union, both politically and economically, remains equally uncertain. What is worth emphasizing not only on the internal EU scale but also in external relations. The Juncker's Plan, which was a punt to launch a public debate on the future of the Community, did not get implementation in the form of adopting a road map for system solutions. Numerous populist movements more and more often postulate dissatisfaction with attachment to the values proclaimed by Brussels. Irresponsibility for the words brings the effect of a snowball, the effect of which is, for example, the decision of the United Kingdom to withdraw from the Community.

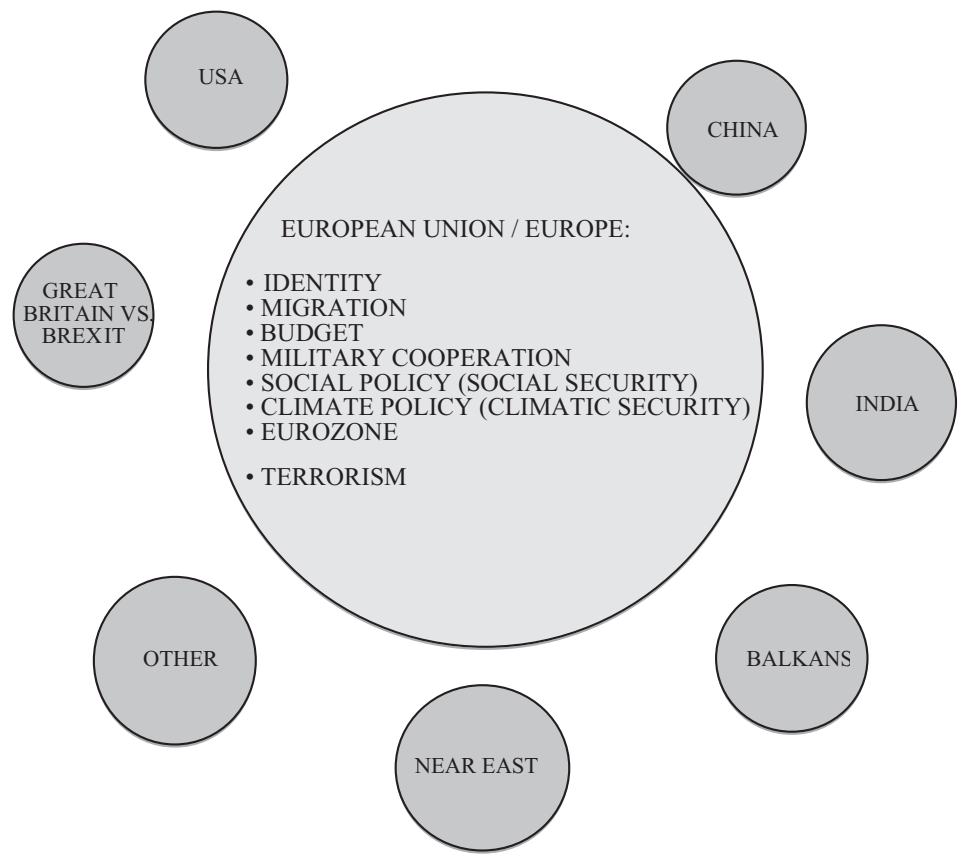

Fig. 1. Impacts on Europe

Source: own source.

Against this background, the unity of Central and Eastern Europe also seems to be illusory. Although the seemingly convergent policy pursued by the Visegrad Group states brings some results, also it is not devoid of differences, it brings different shades of gray and an approach even in the field of the euro currency. Slovakia is in the euro area and prepared for this in the near future, the Czech Republic and Hungary seem to be much more prepared for the challenges of the coming years than Poland. The 
theme of reluctance to migration, induced by populism, seems to combine all the capitals of the region in its rhetoric. However, when we look at the facts, it turns out that the Hungarians have adopted a fixed number of people in the territory of their country. The approach to Russia is also divided in some areas.

Over the last years there has been a significant qualitative change in the perception of the geopolitical environment around us. A quarter of a century ago, theme one was the threat of global war. At present, challenges and threats of transnational character and new political systems of forces that affect the shaping of the environment closest to us come to the foreground ${ }^{1}$.

\section{European Political Checkerboard}

The strategic reorientation of the United States takes the form of their return towards Asia and the Pacific. This means changing the Cold War paradigm that placed global rivalry on the East-West line in Europe. This phrase has already been expressed in the US Strategic Defense Guidelines of January 2012. In this context, a new challenge arises from European NATO members - Europe must take European security issues more than ever before, which is reflected in the declaration of cooperation between NATO and the European Union.

In the case of NATO, for several years now there has been a clear pattern of structures that are changing and reforming, expressed both in the approach to the challenges, threats of today's world, but also in the way of management. In this respect, the political consensus not only of the main European NATO players but also the convergence of looking by members from Central Europe is emphasized.

Only a few years ago, the resistance observed among some of the partners from the Old Continent to strengthen the European security component has weakened significantly, and cooperation programs such as PESCO have become a complement and a reinforcement for actions to improve security. The NATO summits in Newport, then in Warsaw and in Brussels (the decision triad) were also a significant confirmation of support for the idea of strengthening the so-called Alliance's eastern flank among key European partners².

\footnotetext{
${ }^{1}$ H. Thomas, Europa (Europe), Warszawa 1998, pp. 28-32.

${ }^{2}$ H.P. Bartels, A.M. Kellner, U. Optenhogel, Strategic Autonomy and the Defence of Europe. On the Road to a European Army?, Bonn 2017, pp. 19-21.
} 
It is not without significance to maintain the position of Central and Eastern European countries in the context of security guarantees in the region, expressed in the original declaration at the Bucharest Summit in 2015. The talks should be continued in order to maintain the declaration of will to cooperate and support Ukraine.

However, looking through the prism of the global situation, it is worth paying attention to the fact that Poland's international position and the entire region of Central Europe, though touched by various challenges, includingpolitical, internal, but also external and local conflicts (for example, the conflict between Russia and Ukraine, the situation in the Middle East, the unstable situation in North Africa, etc.) seems to be currently stable, though uncertain. What's more, in the near future this state should not undergo significant changes. Nevertheless, it is worth carefully observing and analyzing the possible development of the international situation.

The globalization of world economy makes it susceptible to the possibility of interrupting the supply lines. But there are also other threats: hybrid war, organized crime, misery, which lead to extreme behavior, piracy, migration, also religious fundamentalism and other such behaviors.

Against this background, it is worth noting that the membership in the European Union largely determines the basis of the guarantee for Poland and the V4 countries. Anchoring in the Community radically increased the possibilities of implementing policies and capabilities of international influence. It has strengthened the position of Poland and its partners in the world, but at the same time it has increased its responsibility for the shape of the international order, despite the crisis of the Union's structure with which we are dealing today ${ }^{3}$.

Through to such instruments as: Common Foreign and Security Policy, Single European Market, common trade policy, Cohesion Fund and other mechanisms supporting development, cooperation in the judiciary and internal affairs, participation of Poland and Central European countries in the EU positively affect both security and and development opportunities of the state in all dimensions of political, economic and social life. At the same time, the security of the V4 countries is increasingly an integral part of EU security ${ }^{4}$.

Therefore, it should be emphasized in this context that an important forum for ensuring Poland and at the same time influencing the shape of

${ }^{3}$ Z. Brzeziński, Wielka szachownica (Big Chessboard), Warszawa 1998, p. 253.

${ }^{4}$ Europa Środkowa: wspólnota czy zbiorowość (Central Europe: Community or Collectivity), ed. R. Zenderowski, Wrocław 2004, pp. 64-67. 
the regional and global environment alongside NATO - is the European Union. It is in the interest of the region's states to strengthen the Union's position in the world and increase its international involvement and competitiveness on a regional and global scale. It is important to reform it in response to the crises it faces, but reforming in an evolutionary way rather than a revolutionary one that is often mentioned in the public debate.

Particular attention is paid to actions to increase the activity of the Union in Eastern Europe. Poland supports the EU's commitment to easing tensions and resolving conflicts, especially in the immediate neighborhood of the Union, including in the area of Ukraine. It is important for Poland to gradually increase its share in EU development assistance, considering it an important instrument contributing to the elimination of the sources of many contemporary threats ${ }^{5}$.

Considering that in the nearest years to the most urgent threats in the area of energy policy affecting security policy, it will be possible to include: circling Poland via transmission lines from Russia to Western Europe, which causes us to be cut off from the West in the field of transit and distribution of oil and gas - this is related to Russia's treatment of energy supplies in terms of measure of political pressure; making supply dependence on the state of relations with producers and exporters of energy carriers (Russia) and transit states (Ukraine, Belarus), as well as the threat of destabilization in these countries; physical interruptions in the supply of energy resources, as exemplified by the gas crisis of early 2009 - diversification of supply sources and the level of energy independence (not only oil and gas, but also coal and electricity) remain key.

When it comes to a security and effective European Union, the issue of energy security appears immediately. The Union should have instruments and mechanisms that will enable it to help even individual Member States who would be threatened by a dramatic decline in the supply of energy resources. At the same time, in the context of the Nord Stream 2 project, it seems reasonable that the Community speaks with one voice ${ }^{6}$.

Considering that in the nearest years to the most urgent threats in the area of energy policy affecting security policy, it will be possible to include: circling Poland via transmission lines from Russia to Western Europe, which causes us to be cut off from the West in the field of transit and distribution of oil and gas - this is related to Russia's treatment of

${ }^{5}$ White Book on National Security of the Republic of Poland, National Security Bureau, Warsaw 2013, pp. 109-111.

${ }^{6}$ E. Lucas, Nowa Zimna Wojna (New Cold War), Warszawa 2015, pp. 217-222. 
energy supplies in terms of measure of political pressure; making supply dependence on the state of relations with producers and exporters of energy carriers (Russia) and transit states (Ukraine, Belarus), as well as the threat of destabilization in these countries; physical interruptions in the supply of energy resources, as exemplified by the gas crisis of early 2009 diversification of supply sources and the level of energy independence (not only oil and gas, but also coal and electricity) remain key.

In this respect, the problem of the lack of adequate investments in energy infrastructure is growing. Energy companies are becoming more and more ineffective, increasing energy costs. For the countries of our region, perhaps an alternative solution to this problem may be cooperation within the framework of the Three Seas Initiative, but still maintaining the balance in relations with the whole Community to which we belong.

From the point of view of Polish foreign policy, apart from active membership in NATO and the EU, Poland should still remain an active member not only of the Visegrad Group but also of the Weimar Triangle, now clearly marginalized. It should not be forgotten that after the British withdrawal from the European Union - the two strongest players - Germany and France will play a key role in shaping European policy. The marginalization of Poland's position and its confrontational voice in the public debate will not only serve us but also the other states of the region. Therefore, bilateral relations with both Berlin and Paris should be key, although it is impossible to forget about other bilateral relations. From the Polish perspective, there are several particularly important directions of bilateral cooperation, unfortunately sometimes severely tarnished in recent months.

The elections both influenced the shape of European foreign policy in Germany, France, as well as in the United States. Therefore, proper, properly defined short-term goals of foreign policy action towards key partners and conclusion of appropriate agreements with them, giving rise to joint declarations on the international forum, in particular in difficult areas such as: refugees, migration, European integrity, maintenance of the Schengen area, EU-Russian Federation relations. In this context, the above situation is also a "test" for the functioning of cooperation within the Visegrad Group and the Weimar Triangle.

Due to the varying focus of emphasis and priorities in the policy of the V4 countries, it is important to set short and medium-term priorities for action, as part of the catalog of interests of all member states. The leading role in this process should include Poland as a stakeholder, setting the main trends based on the "balancing art" between east and west of Eu- 
rope, taking into account the context of refugee and migration issues that the continent is currently facing.

In the dimension going a bit further beyond the V4, growing on a counterproposition to the policy currently being pursued by Brussels, the Three Seas Initiative, unfortunately, can only deepen the differences in perception of the European Union and the development of a new model of its identity and way of acting for the next years. Therefore, it is important to emphasize that the European Union, both for Poland and the entire Visegrad Group, should constitute the main pillar of activity and a permanent foundation for cooperation on which other fields of regional cooperation are based.

The maintenance of good contacts remains important for foreign policywith EU institutions. In this context, the positive message from Warsaw about the will to cooperate in favor of a strong European Union, based on the internationally developed, medium-term, mature and deepened vision of Polish membership, which also takes into account the proper use of EU funds allocated to Poland, remains important in present and future financial perspectives. In parallel to the above, a comprehensive, in-depth analysis of changes taking place within the Community and in the world is necessary, with particular emphasis on threats lying in the orbit affecting the security of the European Union and its citizens, with particular reference to the context of terrorism.

To ensure the integrity and solidarity of the Community, activities to minimize eurosceptic votes among the citizens of some Member States, prudence in the decision-makers of Eurosceptic and critical opinions towards the European Union, especially in the context of the possibility of reaching the fertile ground of populism in the name of a short-term political goal.

\section{Emerging Powers}

Against the background of the regional situation in Europe and the $\mathrm{Eu}-$ ropean Union's identity vision itself, the key issue of relations with China is growing, which plays an increasingly important role in international politics today. It is in the interest of Poland that, as a permanent member of the UN Security Council and the "emerging power", China should adequately address its position and potential in solving global problems.

The common interest of the European Union, NATO and China lies, among others, in cooperation in the field of arms control, combating terrorism and WMD proliferation, and enhancing security in the wider Middle East region. 
As part of ensuring the optimization of cooperation and increasing the competitiveness of the European market, the topic of joint talks not only with China, and possiblybut also with India may be, among others, energy policy, including relations with Russia and the countries of Central Asia in the aspect of acquiring energy resources or technological development. The expansion of human capital will also be important in the future.

\section{An Invisible Enemy}

An important factor influencing the shaping of the current international order is still terrorism. It is a danger to citizens' lives, stability of democratic institutions, state infrastructure and other elements of its proper functioning.

Terrorism motivated by radical islamic ideology is a special variant of terrorism. Characteristic is the attempt to transfer the burden of activity to the interior of the Western world in the form of intensification of the phenomenon of native terrorism ${ }^{7}$.

The resurgent extreme-left, ultra-right and national-separatist terrorism is different in ideological roots and motives. It is a threat mainly for European countries - it has its sourcein extremist ideologies, xenophobia, reluctance towards immigrants, the economic crisis and public dissatisfaction with the actions taken by governments, and other factors.

In this context, marginalized and nationalist activities will probably pose a growing threat to the stability of democratic systems. The confrontational attitudes towards the allegedly progressing islamization of Europe intensify. They negate the idea of multiculturalism and openness, which is particularly evident in the example of migration to Europe.

In the context of terrorism itself, cyberterrorism, which is a part of a wider problem of cyber threats, is becoming more and more important.

Up to a certain point, virtual space on a large scale was used by terrorists mainly for propaganda, training and recruitment activities. At present, a new quality and tendency to transfer strictly terrorist activities to cyberspace (attacking ICT networks and technological systems of strategic importance for the state) is observed. It is worth emphasizing that the problem of cyber threats is much wider. It's not just cyberterrorism. Both the authorities and services of hostile states, ready to carry out a kind of information war, as well as large concerns, non-governmental and supranational organizations, including criminal organizations, can resort to activities of a cyber-aggression nature.

\footnotetext{
${ }^{7}$ White Book..., op. cit., pp. 115-117.
} 
External threats to Poland and the Visegrad Group countries, in the traditional sense, now and in the near future seem unlikely. Trans-sectoral threats seem to be much more real, for example those related to cyberspace.

Potentially real appear to be terrorist attacks on the network, hacking attempts to take over data or blocking websites and other constantly evolving ICT activities aimed at depriving the lack of control over information or taking over information. It is necessary to develop solutions, both domestic and those of an EU nature, to prevent and combat emerging threats in a coordinated manner, in particular to quickly and effectively respond to attacks against systems, ICT networks and services offered on the network or its use.

The complex character and dynamic changes taking place in the international environment force the need for a comprehensive look at all its aspects. Threats of a cybernetic nature are a new type, interdisciplinary and global: they can touch various areas and areas essential for the proper functioning of states, and an attack can be carried out by a single hacker from any point on the globe. Due to the unconventional and international character of these threats, intensification of cooperation and exchange of experience between states and relevant institutions isdesirable.

\section{Migrations in the Shadow of Demographics}

In addition to changes of political nature or affecting the sphere of functioning of states and nations, it is worth paying attention to another social dimension, Poland and the entire European continent will have to deal within the coming years.

There are unfavorable demographic changes affecting the state of social securityin countries of Central and Eastern Europe. In Poland, there was a slight increase in the fertility rate, however, this increase is temporary and results from the entry of baby boomers from the eightiesinto the procreative age. All scenarios show inevitable decline in numbers, progressive migration within the European Union, inflow of migrations from outside the Community and acceleration of the aging of societies.

There is a trend observed for several years, which is reflected by Poles who have become much more mobile and "courageous" in the exploration of the world. This trend has its roots in a number off actors. If only the period of time from the accession of our country to the European Union and including the gradual release of labor markets is accepted -it's clearly visible that the dominating cause of migration was the economic factor, the desire to improve well-being and development. The above elements 
were crucial especially for young people, up to about 30 years old, born in the period of baby boomers, for whom new, favorable geopolitical changes were mainly an opportunity, and the living conditions on the domestic labor market often proved much less competitive than in the nearest European environment. What, however, important migrations from about a decade ago were much more likely to take on a short-term character, based mainly on the employment and educational.

In recent years, however, a new phenomenon is emerging - long-term or even long-term migrations, clearly defined as to the objectives, where the only gainful factor plays less importance. The improvement of the quality of living on the local labor market, the increase in the level of remuneration and their partial equalization in relation to the standard of living on external markets, and increased mobility - this is a simplified part of the elements affecting emigration decisions. However, two elements remain crucial in the context of the decision to go abroad. First of all, the majority of those declaring to leave our country are young or middle-aged people, and second - nearly $1 / 4$ of people want to do it permanently ${ }^{8}$.

What's more, the correlation between the age of the emigrants and the time of staying abroad in combination with the demographic factor takes on a completely new, particular significance for the shaping of social policy. If we assume that the data and assumptions of the Central Statistical Office of 2016 will be confirmed and the share of older people in the population of Poland will increase from $21.5 \%$ in 2013 to $40.4 \%$ (13.7 million) in 2050 - with a). maintaining the migration trend of young people in subsequent years, b). maintaining the homogeneous structure of the population structure and c). tendency to close to migrants coming to the European Union and directly to Poland - we are threatened with the crisis of the entire labor market system as well as social assistance. In this context, it seems crucial to redefine and return to the concept of a comprehensive, long-term strategy of action aimed at creating a comprehensive policy of integrating foreigners in Poland based on various factors, such as: substantive, political, legal, institutional and social aspects. We should realize that the tendency to migrate some Poles to stay long or permanent outside our territory, but also in the face of the changing image of the surrounding world - the inflow of migrants to Europe is unstoppable. We can observe similar phenomena in other countries of our region, too.

The approach, taking into account, among other things, the economic and geopolitical dimension, as well as referring to negative demographic

\footnotetext{
${ }^{8}$ Ibidem, p. 119.
} 
trends in the future - should create and create indications to supplement human resources in the labor market in the perspective of the next two or three decades, conducive to ensuring the social security of the state.

The decline and aging of the population will have a negative impact on the entire social system, including: the labor market, pension system and political system (increasing conservatism and unwillingness to reform), which may put into question the ability of Poland and the V4 to continue the rapid pace of civilization development. In other words, weakening the social (demographic) security of the state will also have a negative impact on its security system, as a whole.

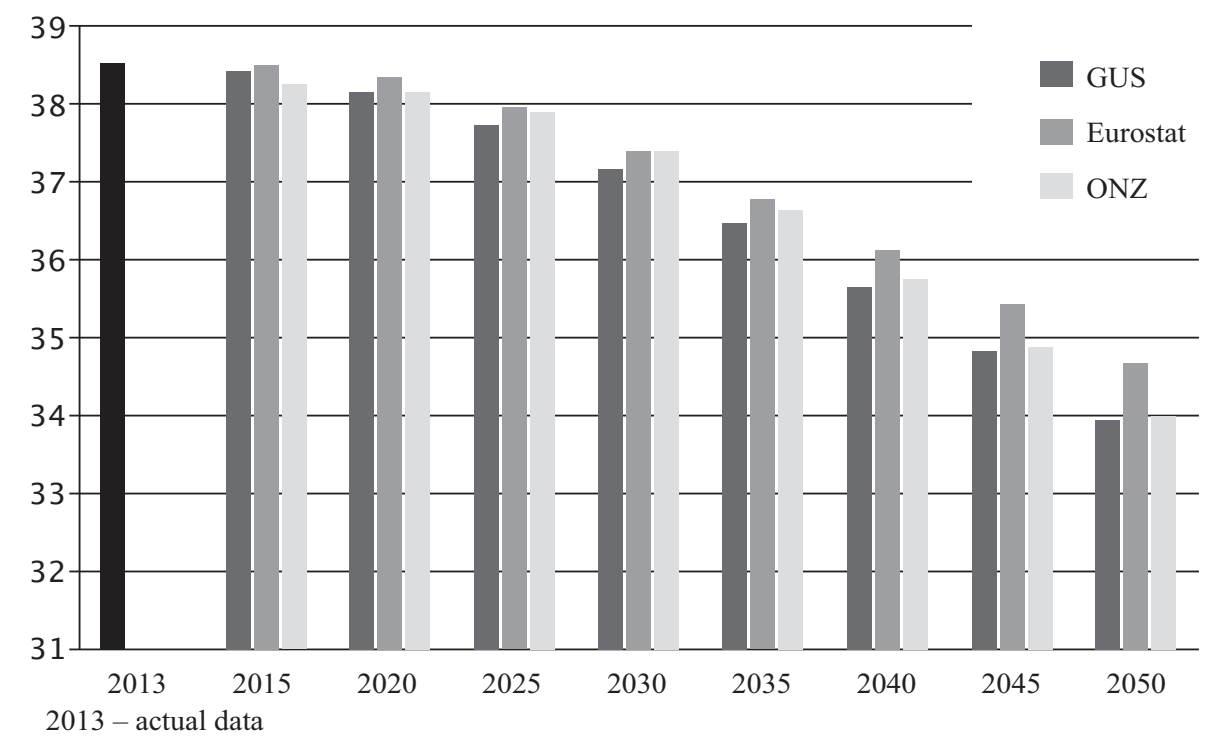

Fig. 2. Demographic trend: population forecast for Poland (in millions)

Source: Population forecast for 2014-2050, Central Statistical Office, p. 163.

In the current situation, there are justified fears that the socio-economic crisis we may be witnessing in the future will result in social disadvantages that are difficult to quantify. The reform of the social system and ensuring social security seem to be indispensable. It is worth remembering that in this situation, it is not a solution to increase social benefits provided to citizens by states, but to create systemic, comprehensive solutions and also based on ensuring proper education.

The catalog of negative social phenomena which should be undertaken for intervention and education is long: migrations, emigration of the young generation, lack of a systemic pro-family policy, a feeling of 


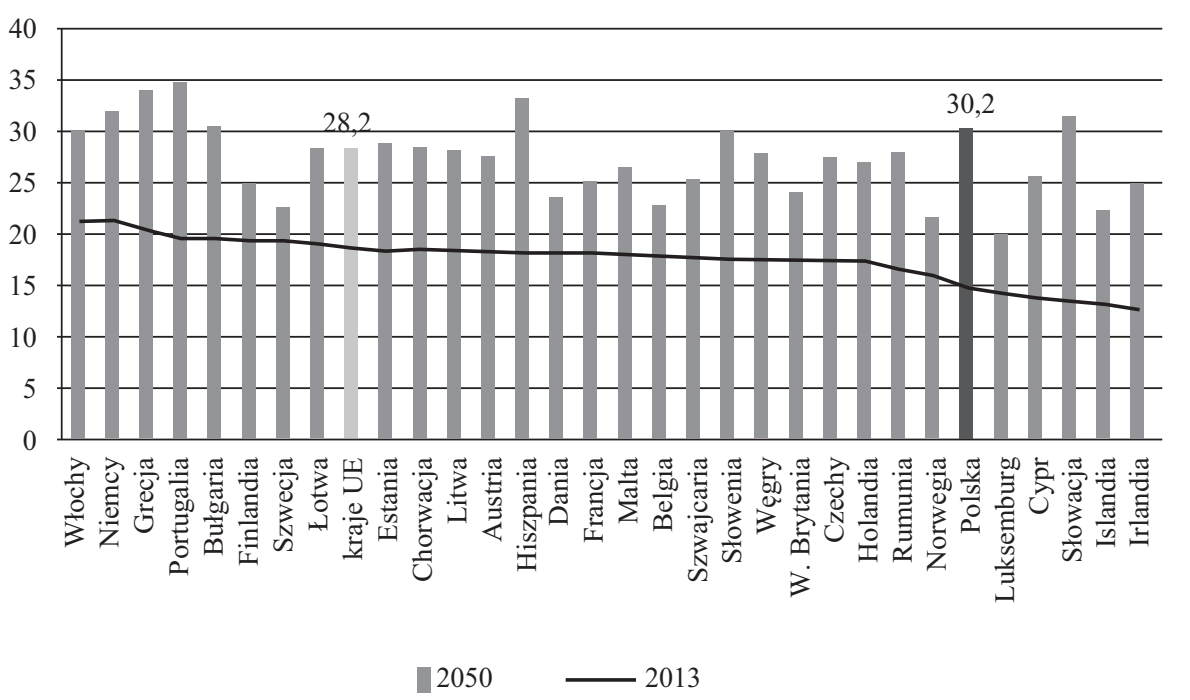

Fig. 3. Share of people aged 65 and more in the total population of the European Union in 2013 and 2050

Source: Population forecast for 2014-2050, Central Statistical Office, p. 166.

helplessness in confrontation with a bureaucratic machine, inequalities resulting from sex and age that are difficult to place of residence and access to knowledge.

\section{Ecology - a Ticking Bomb}

The real challenge to the international environment are natural or man-made disasters, which are an inseparable element shaping the security conditions.

The high level of human activity, which is still systematically growing, on many - often high risk - fields of activity (eg. energy, mining industry, interference in the natural environment) will obviously generate a threat of large scale disaster events, about potential effects on property, health or human life. Particularly due to the fact that in the coming years Poland will still belong to developing countries and often catching up with highly developed countries will be associated with underinvesting and the necessity to use outdated elements of infrastructure or technological solutions, and thus the risk of occurrence will increase disasters?.

The same applies to natural disasters caused by natural factors, such as heavy rainfalls, floods or violent winds, hurricanes and whirlwinds. In ad-

\footnotetext{
${ }^{9}$ Ibidem, p. 233.
} 
dition, the increase in temperature on the earth's surface, in a measurable way, will also determine migration flows in the coming years, in particular on the territory of Central and Northern Europe.

\section{Conclusion}

When analyzing the international situation in the background of which Poland and other countries in the region occur, it should be emphasized that political, social and economic factors are of particular importance, followed by defense issues. One might even be tempted to say that the international environment is mostly livelihood or in the near future will be natural disasters in the social sphere. Just like natural disasters, these are also consequences of civilization development, including, for example, the development of democracy. The occurrence of large-scale threats in the defense area is now much less likely, both now and in the foreseeable future. This does not mean, however, that this sphere can be neglected.

In the new reality of international relations, the European Union should gain in significance, since it has even greater influence instruments than NATO, including those related to the so-called soft power. This does not mean, however, that the EU will replace NATO in the near future. Both organizations should remain complementary to each other, acting together cornerstone of European policy dimension of security and stability.

The necessity fora comprehensive approach towards the challenges of today's world means that there is a need to develop mechanisms to overcome the political deadlock within the European Union and to seek ways to build the organization's identity again.

The enlargement of European and Euro-Atlantic institutions to the East in the last twenty years has contributed not only to an increase in the level of security in Europe, but also to the creation of stability and development opportunities. To strengthen stability and predictability, the process of diffusion of values and standards on which the democratic rule of law is based is of fundamental importance. Therefore, one should hope that the process of NATO and EU enlargement will not only be continued in the coming years, but their development will be stable.

Moreover, it is unquestionably in the interest of Poland and the V4 states to have a strong, effective, politically and militarily cohesive North Atlantic Alliance, where all countries will not only act as beneficiaries, but also actively participate in the activities undertaken within the Alliance. After Poland joined NATO, the second phase of development of our national defense policy began, the main content of which is, on one hand, 
the transformation of our own security system, according to the changing conditions of membership in NATO and the European Union, and on the other - gaining experience in allied structures, including in their active shaping according to their own national interests. Membership in the European Union creates an excellent opportunity to pursue the interests of our country in this forum. Both organizations are the backbone of ensuring our development and as their full member we must actively seek to ensure that they are based on the principle of equal security status and have the means and capabilities to provide credible protection of the territory and the interests of its members, both in military and ascending recently on the importance of the non-military aspect.

Speaking of the current international environment, we should remember that the boundary between the internal and external aspects is increasingly blurred, and the processes of globalization - understood as a network of mutual connections - blur this border even further. Poland's participation in the NATO forum or integration within the EU - economic, political and social - can be a source of challenges for the internal situation of the state. Challenges in the sphere of economic, demographic, energy or climate change do not concern individual states but become subject to debates within institutions or supranational structures. The effect of the information revolution - which impresses the greatest mark on all contemporary human activity, and in this and on security - is the need to ensure security in the network, or cybersecurity ${ }^{10}$.

The time is coming to integrate efforts and activities, in which a comprehensive approach to challenges - including economic, energy, social and climate change - becomes a key element in strategic thinking about the international environment.

It is worth acknowledging that in the regional, European dimension there is no reason to believe that in the long-term the model of Europe as a continent without armed conflicts will be permanent, especially if there is a serious disruption of the EU, the euro collapse or even the disintegration of the European Union. On the outskirts of NATO and the EU, there may be armed conflicts of a limited nature that will change the political situation and will also have a negative impact on the security of Central European countries. Although there are no countries or their groupings that would have explicit intentions of armed aggression on the territory of the nearest neighborhood in the medium term. However, the country's security may be adversely affected: geopolitical changes in the neighborhood of the country; from the point of view

${ }^{10}$ R. Olszewski, Bezpieczeństwo wspótczesnego świata (Security of the Modern World), Toruń 2005, pp. 106-107. 
of Polish interests, a different approach in shaping the neighborhood policy (eg. with Germany on energy issues and relations with Russia at the expense of Euro-Atlantic solidarity); attempts to make Poland dependent on supplies of raw materials, political pressure with reference to the threat of military force, uncontrolled arms, unconventional terrorist attacks and cyber attacks.

The ongoing changes in the European situation resulting from the significant reduction of the attractiveness of the European Union's political and economic model, as well as the limited ability and willingness of the United States to engage in European security issues is one of the key challenges we are currently facing. The development of events according to the scenario in which the Europe of many speeds will dominate, i.e. the intensification of the fight to expand or maintain the zones of influence of individual states and organizations, would be a serious challenge for Poland and V4.

The European Union will have to take into account the interests of all its members and face the assertive attitude resulting from the fact that not all consider the current model and shape of the EU as the best, and integration with the Union as an overarching political goal.

In this context, it is also worth paying attention to a slightly wider geopolitical dimension, including relations with Turkey. Its rapid economic growth is accompanied by increased ambitions in foreign policy. It's time to break with the stereotypical view of Turkey as a poor relative of Europe, politely knocking at the gates of the EU. Turkey is on its way to becoming a regional power, which will finally make full use of its unique geographical location beyond the crossroads of Europe, the Middle East and Asia. Equally worrying in the future may be the rapprochement between Turkey and Russia, especially in a situation where for Ankara, both the European Union, and the more NATO will cease to be an attractive platform for cooperation.

Undoubtedly, therefore, in an increasingly multi-polar Europe, which is threatened with disintegration into the spheres of influence, it is necessary to develop a new model of cooperation for new challenges. On the one hand, the EU-NATO alliance may be the answer, especially in a situation where the United States does not want to engage in the internal problems of European security on a scale as we would expect. On the other hand, the geopolitical situation may force you to start a tripartite dialogue on the line European Union, Russia and Turkey - on the new architecture of the relationship and vision of security in Europe.

In order to properly and comprehensively diagnose and develop solutions that will largely analyze the strategic situation of the international 
environment and its security dimension, it would be worth returning to the idea initiated by the National Security Bureau in 2010, i.e. to launch a new edition of the National Security Strategic Review (SPBN) under the auspices of the President of the Republic of Poland, giving in accordance with the assumptions adopted in the National Security Strategy of the Republic of Poland, a cyclical dimension.

\section{References}

Bartels H.P, Kellner A.M., Optenhogel U., Strategic Autonomy and the Defence of Europe. On the Road to a European Army?, Bonn 2017.

Brzeziński Z., Wielka szachownica (Big Chessboard), Warszawa 1998.

Europa Środkowa: wspólnota czy zbiorowość (Central Europe: Community or Collectivity), ed. R. Zenderowski, Wrocław 2004.

Lucas E., Nowa Zimna Wojna (New Cold War), Warszawa 2015.

Olszewski R., Bezpieczeństwo wspótczesnego świata (Security of the Modern World), Toruń 2005.

Population forecast for 2014-2050, Central Statistical Office, 2014.

Thomas H., Europa (Europe), Warszawa 1998.

White Book on National Security of the Republic of Poland, Warsaw 2013. 